\section{New NSF Director and Presidential Science Adviser Named}

In February, President Clinton named Rita Colwell the new director of the National Science Foundation. Dr. Colwell is currently president of the University of Maryland Biotechnology Institute and deputy director of the National Science Foundation. She will replace current NSF Director Neal Lane, who has accepted Clinton's invitation to serve as presidential science adviser and director of the Office of Science and Technology. Both Colwell's and Lane's appointments are subject to Senate confirmation. Hearings have not been scheduled as of this writing.

The Clinton administration has made a commitment to increasing federal expenditures for nonmilitary research and development, and its recently submitted budget proposals call for dramatic increases for all federal science agencies.

Despite demands from some Congressional Republicans that federal research funds be directed to applied projects, Clinton has repeatedly called for greater support for basic research. The two nominations reflect the administration's preference and, according to John Podesta, Clinton's deputy chief of staff, the selection of biotechnologist Colwell to head NSF further underscores the administration's desire to promote greater synergy among the sciences.

Howard Silver, executive director of the Consortium of Social Science Associations, praised both appointments, noting that Lane's elevation to the top science post in the government was especially propitious because Lane has "convinced the White House that NSF deserves equal billing with NIH as a major funding agency for basic research."

membership offer or the Association in general, visit our web site (www. apsanet.org), or contact Sheilah Mann, Director, Education and Professional Development, APSA, 1527 New Hampshire Ave., NW, Washington, DC 20036; Phone: (202) 483-2512; Fax: (202) 483-2657; Email: smann@apsanet.org.

\section{Bennett Proposes Reorganization of NSF's Directorate of Social, Behavioral, and Economic Sciences}

Bennett Bertenthal, head of the National Science Foundation's Directorate of Social, Behavioral, and Economic Sciences (SBE), has revealed a plan to split the research division of SBE into two divisions tentatively titled the Division of Behavioral and Cognitive Sciences (BCS) and the Division of Social and Economic Sciences (SES). The reorganization, scheduled to take place later this year, is subject to Congressional approval.

The split is primarily intended to increase the efficiency of the research division. Currently, the SBER "handles the second largest number of applications within the Foundation," according to Director Bertenthal. "It makes the largest number of awards. And it has the largest number of program directors. The difficulty of reaching a consensus-because of how large the division is-often increases the amount of time needed to make decisions," Bertenthal continued.

Under the proposed reorganization, BCS would house the existing programs in archaeology, physical anthropology, cultural anthropology, social psychology, linguistics, human cognition and perception, and geography and regional sciences. SES would assume the programs in economics, political science, law and social science, sociology, ethics and values studies, science and technology studies, methods, measurement and statistics, cross-disciplinary activities, and decision, risk, and management sciences. "The new arrangement allows individuals who share a great deal more in terms of both methods and approaches to research to work together," noted Bertenthal.

\section{Section News}

\section{Foundations of Political Theory}

The Foundations Organized Section is now online at www.apsanet. org/ theory. The web site includes access to the section newsletter, awards, and bylaws; announcements; contact information for the officers and council of the section; a page devoted to recently published books in political theory; and an index of online resources for theorists. These include journals, associations, research institutes, grants and fellowships, course syllabi, conference announcements, online texts in political theory, and links to sites devoted to particular theorists.

To make suggestions for what the site should include in the future, or to submit a link, contact theory@ apsanet.org.

\section{Presidency Research Group}

The Presidency Research Group (PRG) will conduct a campaign to endow fellowships supporting research on the American presidency. With an interest in explaining the relationships, institutions, and environment surrounding the President, the Group will fund the work of individuals whose scholarly research brings them to the Washington area. Whether the scholar comes to Washington for archival work, library research, or interviews with key offcials, PRG is interested in having a place where people are supported as they conduct their work. Depending upon research needs and the Group's resources, the fellowships will support a scholar's stay of one to three months at the planned APSA Centennial Center for Political Science, and, in some cases, a modest travel sum. The Centennial Center will be housed in the APSA National Office and opened in 2003 as part of the Association's 100 th anniversary.

\section{Domestic Sources of Foreign Policy}

Agenda items to be covered at the Section's business meeting at the 1998 Annual Meeting in Boston include: (1) approval of Section consti- 